\title{
PIONEER
}

VOLUME 11, Issue 1, June 2019: 12 - 20

\section{THE ANALYSIS OF SOCIAL DEIXIS IN THE MOVIE BEAUTY AND \\ THE BEAST}

\author{
Igaratu Noerrofi'a \\ University of Abdurachman Saleh Situbondo \\ igaraturofia@gmail.com \\ Syaiful Bahri \\ SMAN 1 Situbondo \\ bahrisyaiful1969@yahoo.com
}

\begin{abstract}
Social deixis usually can be found in movies. So that, this study purposed to describe the kinds of social deixis and aims of social deixis in the movie entitled Beauty and the Beast. The writers analyzed this study by using theory of Stephen C. Levinson. In analyzing the data of this study, the writers used qualitative method. The findings of the analysis revealed that there were 34 utterances that containing social deixis found in the movie Beauty and the Beast. The writers found 68 styles of social deixis in the movie Beauty and the Beast, 34 styles of social deixis were categorized as kinds of social deixis and 34 styles of social deixis were categorized as the aims of social deixis. The writers found two kinds of social deixis, they were; 18 styles of social deixis in relational social deixis and 16 styles of social deixis in absolute social deixis. Besides the writers found, three aims of social deixis, they were; 9 styles of social deixis have categorized as to express politeness and respect, 18 styles of social deixis had categorized as to express intimacy, and 7 styles of social deixis had categorized as to identify authority.
\end{abstract}

Keywords: social deixis, kinds of social deixis, aims of social deixis

\section{INTRODUCTION}

Language is an important aspect for human life which is always used by human to communicate each other. According to Ronald Wardhaugh (1972:3) language is a system of arbitrary vocal symbols used for human communication. It means that language is an aspect that cannot be separated from the life of all human in the interaction. Additionally, communication will be done in right way if it occurs communicatively. Of course, it can be separated from what the speaker says and what the addressee heard. However, communication does not always come from the same background, such as: gender, social background and status, and also age. So, they may use various language styles in speaking and sometimes it makes the sentences they utter 
hard to be understood or seems strange to another people. The differences background means that differences can be demonstrated in the choice of words.

In this case, pragmatics is used because pragmatics is the study of how more gets communicated than is said (Yule, 1996:1). Deixis is a part of pragmatics study. Whereas, in having communicative ways, the right usage of deixis becomes an important factor in building a success communication because deixis is making clearance on communication (by describing better and explaining better, by pointing out particularly referring to the background and the environment).

In this research, the writers only focus on social deixis. Social deixis can be reflected in literary work. One of the literary works is movie. Movie has an important role in recent society since it exposes many issues in daily life. Social deixis can be found easily in the movie Beauty and the Beast.

By using Levinson's theory, the writers tried to analyze the kinds of social deixis and aims of social deixis in the movie Beauty and the Beast. The objectives of this study were to know what kinds of social deixis and what aims of social deixis in that movie.

Pragmatics is a branch of linguistics that is related to the meaning. Levinson (1983:9) states that pragmatics is a study of those relations between language and context that are grammaticalized, or encoded in the structure of a language. Pragmatics is a part of the study of language that investigates technique with language which is used for communicational purpose, studies how language uses of their understanding in mind of the language structure and rules. Then, it can be interested the process of producing language based on the context. Pragmatics can analyze what people mean by their utterances than what the words or phrases in those utterances might mean by themselves.

Deixis is a technical term (from Greek) for one of the most basic things we do with utterances. It means "pointing via" language. Any linguistic form used to accomplish this "pointing" is called a deictic expression. Levinson (1983:54) says that the single most obvious way in which the relationship between language and context is reflected in the structures of languages themselves, is through the phenomenon of deixis. Deictic expressions are also sometimes called indexical. 


\section{Types of Deixis}

Deixis implicates not only the characteristic functions of the demonstrative pronouns but also tense and person, and a number of other syntactically relevant features of the context of utterance. As quoted from Levinson's book "Pragmatics" there are five kinds of deixis, they are: person deixis, time deixis, place deixis, discourse deixis and social deixis. Person deixis clearly operates on a basic three parts division exemplified by the pronouns for first person (I), second person (you), and third person (he, she or it). Levinson (1983: 62) states: Person deixis concerns with the encoding of the role of participants in the speech event, in which the utterance in question is delivered: the category first person is the grammaticalization of the speaker's reference to himself, second person the encoding of reference to one or more addresses and third person the encoding of reference to persons and entities which are neither speakers nor addresses of the utterance in question.

The concept of distance already mentioned is clearly relevant to locative expression or place deixis, where the relative location of people and things is being indicated. Place deixis show itself principally in the form of location adverbs such as here and there. English has a relatively impoverished place deictic system, with two terms there are proximal and distal. The proximal term here means something like "region relative close to the speaker", and there means "relatively distant from speaker".

Temporal or time deixis concerns with the encoding of temporal points and spans relative to the time at which an utterance is spoken. Temporal deixis is commonly grammaticalized in deictic adverb of time (like English now and then, yesterday and this year) but above all in tense. English has two basic forms of tenses, there are present and past tense.

Discourse deixis concerns with the use of expression within some utterance to refer to some portion of the discourse that contains the utterance. The deictic word used here are the demonstratives this and that. This can be used to refer to a portion of the discourse and that to a previous portion. Discourse deixis deals with "the encoding of reference to portions of the unfolding discourse in which the utterance (which includes the text referring expression) is located" (Levinson, 1983:62).

Social deixis concerned with the encoding of destination that are relative to participant roles, particularly aspect of the social relationship holding between speaker 
and addressee (s) or speaker and some referent (Levinson 1985:63). Social deixis also concerns on the aspect of sentences that reflect by certain realities of the social situation in which the utterances occurs. Social deixis is reference to the social characteristics of, or distinctions between, the participants or referents in a speech event.

\section{Kinds of Social Deixis}

The analysis on the kinds of social deixis is related to the characteristics of the social deixis in the movie. The kinds of social deixis based on Levinson (1983:90) are relational social deixis and absolute social deixis.

Relational social deixis is manifested through a certain relationship between a speaker and an addressee. Furthermore, kinship terms are often applied since they illustrate personal ties or blood bond among the speech participants. According to Archer, Aijmer, and Wichmann, relational expressions (such as kinship terms) are determined by speaker and referent, speaker and addressee (2012: 27).

The deictic words of absolute social deixis cannot be separated from the concept of honorifics. They are often applied to show different social status, higher and lower social status, between a speaker and an addressee. Huang clarified that absolute information in social deixis can be illustrated by forms that are reserved for authorized recipients (Your Majesty, Mr. President) (2007: 162).

\section{Aims of Social Deixis}

The analysis of the aims of using social deixis is related to the social context. Consequently, it also demonstrates how such a context could determine or establish the purposes of using social deixis. context is considered as the most influencing element as it holds the pragmatic essential concept. It is the key that opens the goal meaning or the correct interpretation of an utterance pragmatically. Some aims of social deixis are the followings:

To express politeness and respect

The expression of respect and politeness can be portrayed through the usage of social deictic words. Besides, certain social deictic words, for instance honorific titles are usually used to show the degree of politeness. 


\section{To express intimacy}

The Some of social deictic words related to kinship terms can be used to display how intimate the people are. Moreover, some of social deictic expressions are also applied to manifest a very high degree of solidarity and how people feel close each other.

\section{To identify authority}

The Social deixis encodes the authority of the discourse of participants. Moreover, it is often made use of identifying participants' responsibility and duty in a certain institution or organization. The authority of each speech participant can be explained in detail by investigating deictic words and also the context found in that movie.

\section{Beauty and the Beast}

Beauty and the Beast is an American live-action musical romantic fantasy film directed by Bill Condon and distributed by Walt Disney Pictures. It is a remake of 1991 animated film of the same name, and was written by Evan Spiliotopoulos and produced by Mandeville Films. The script was rewritten by Stephen Chbosky. The film stars Emma Watson as Belle and Dan Stevens as the Prince/Beast. It was released on March 17, 2017. This movie tells about a monstrous prince and a young woman who fall in love. Beauty and the Beast is a story of transformative love, and of learning to see someone's inner beauty, that ends in a blessed matrimony with a handsomeprince.

\section{METHODOLOGY}

In this research, the writers use qualitative research. The writers used qualitative method to analyze what were kinds and aims of social deixis in the movie Beauty and the Beast. The kinds and aims of social deixis that found were described completely using pragmatic approaches according to Stephen C. Levinson's theory.

Descriptive method was used by explaining the kinds and aims of social deixis that occurred in movie Beauty and the Beast. Whereas, the technique of this method was watching and searching the kinds and aims of social deixis in Beauty and the Beast to collect and take the data sources. The writers took the data from the movie Beauty and 
the Beast. Meanwhile, the data of this study were all of the utterances that contained social deixis spoken by the characters in the movie Beauty and the Beast.

There were also some stages in analyzing the data, Miles and Huberman (1994) revealed that there are three steps in analyzing the data. They are data reduction, data display, and conclusion drawing/verification. Data reduction is the process of selecting, focusing, and abstracting data that exists in the movie Beauty and the Beast. In this step, the writers choose some relevant utterances that contained social deixis spoken by the characters in the movie Beauty and the Beast.

Data display was organized information including the final conclusion. The writers classified the scenes based on the data which obtained by the writers while watching Beauty and the Beast. Conclusion drawing stated a temporal result of the study. At last, the writers drew the conclusion based on data analysis which was done in the previous part.

\section{FINDING AND DISCUSSION}

- Datum 1 (ASD1 - AIA1/BB- 00:05:42)

\section{Good morning, Monsieur Jean! Have you lost something again?}

This utterance was actually spoken by people to Jean. The honorific title Monsieur in the sentence belongs to an absolute social deixis. In this case, it refers to a man named Jean. It can be said that he is an aristocrat in France. Furthermore, by having this title, he is considered as a man of great power and he has more dominant position in social hierarchy. Therefore, the title is classified as an absolute social deixis since it describes higher social status owned by nobility.

The term Monsieur is a title in European countries, that works in a French court of law and occupies a status as assistant State of Persecutor. So, the responsibility is to investigate people who commit a crime and prosecute them. In other words, he has power to act on behalf of the state in criminal prosecutions through the state's attorney. Moreover, he must focus on maintaining the law and order in his territory and make sure no one violates the law.

According to the utterance of datum 1, the term Monsieur here is categorized as the kind of social deixis absolute social deixis and the aim of social deixis is to identify authority.) 
- Datum 3 (RSD1 - AEI1/BB- 00:12:40)

\section{Papa, do you think I'm odd?}

This utterance was actually spoken by Belle to Maurice. The kinship term Papa in the sentence belongs to a relational social deixis. Traditionally, a man is called Papa if he already got married and had a child or children. Then, it becomes an addressing term which is used by children to call their male parent. In that movie, it refers to a man named Mr. Maurice. He is Belle's Father. Consequently, it is classified as a relational social deixis since it illustrates a bond of family between Belle as a Mr. Maurice's daughter and Mr. Maurice as Belle's father in that movie.

In that sentence above, the deictic expression Papa illustrates relationship between two people. In this case, it can be applied to show intimacy between a daughter and a father. It can be seen that Belle really loves and cares about her father. Thus, the social deixis Papa is used to demonstrates how intimate their relationship.

According to the utterance of datum 3, the term Papa is categorized as the kind of social deixis relational social deixis and the aim of social deixis is to express intimacy.

Social deixis is a kind of deixis which is interesting to be observed. It concerns with the roles and social relationship (can be differentiated based on the kinship terms or status markers) of speech participants in a communication. The most important component in communication is meaning, an idea or concept. People can communicate each other or create a good conversation because they understand the idea or concept which they share to others. In this case, the speaker should be able to transfer the ideas or concepts that he wants to deliver. Then, the hearer has to catch and comprehend them.

In this study, the analysis of social deixis found kinds of social deixis and aims of social deixis in the movie Beauty and the Beast. The kinds of social deixis were relational social deixis and absolute social deixis. Besides, the aims of social deixis were to express politeness and respect, to express intimacy, and to identify authority.

The writers found some utterances containing conversational social deixis in some dialogues in the movie Beauty and the Beast. Based on the kinds of social deixis, there were 18 utterances categorized as relational social deixis and 16 utterances 
categorized as absolute social deixis. In this case, the dominant kind of social deixis was relational social deixis.

Then, based on the aims of social deixis, there were 12 utterances categorized as to express politeness and respect, 18 utterances categorized as to express intimacy, and 7 utterances categorized as to identify authority. According to the data, the writers concluded that the dominant aims of social deixis in the movie Beauty and the Beast was to express intimacy.

\section{CONCLUSION}

There were 34 utterances containing social deixis in the movie Beauty and the Beast. There were two kinds of social deixis that were found by the writer in this study. They were relational social deixis and absolute social deixis. In this case, relational social deixis is the most frequently used in the movie Beauty and the Beast.

There were three aims of using social deixis that were found in this study. Three aims of social deixis are to express politeness and respect, to express intimacy, and to identify authority. In this case, social deixis was used mostly to express intimacy of speech participants.

The usage of the kinds and aims of social deixis in the movie Beauty and the Beast was useful to clarify social status, social identity, and intimacy of social relationship of people, social level differentiating, to control politeness in speaking, and to control social attitude in society. The social deictic that found in the movie Beauty and the Beast cannot be separated from the role of context of the utterances in that movie. Some examples above has showed that the usage of social deixis in that movie are accurate.

\section{REFERENCES}

Archer, Dawn, Karin Aijmer, and Anne Wichmann. (2012). Pragmatics: An Advanced Resource Book for Students. London: Routledge.

Arikunto, S. (2014). Prosedur Penelitian. Jakarta: Rineka Cipta.

Bergmann, Anouschka (ed), Kathleen Currie Hall, and Sharon Miriam Ross. (2007). Language Files: Materials for an Introduction to Language and Linguistics. Columbus: The Ohio State University Press. 
Creswell, John W. (2009). Research Design Pendekatan Penelitian Kualitatif, Kuantitatif, dan Mixed. Yogyakarta: Pustaka Pelajar. Penerjemah Achmad Fawaid.

Hancock, Beverley, Elizabeth Ockleford, and Kate Windridge. (2009). "An Introduction to Qualitative Research". National Institute for Health Research.

Levinson, Stephen C. (1983). Pragmatics. Cambridge: Cambridge University Press.

Miles, M.B, Huberman, A.M, (1994). Qualitative Data Analysis, 2nd Ed. USA: Sage Publication.

Wardhaugh, Ronald. (1972). Introduction to Linguistics. New York: McGraw-Hill.

Yule, George. (1996). Pragmatics. New York: Oxford University Press. 